\title{
Kefir fermentation as a bioprocess to improve lentils antioxidant properties: is it worthwhile?
}

\section{Fermentação com kefir como bioprocesso para melhorar as propriedades antioxidantes de lentilhas: vale a pena?}

\author{
luri Magalhães de Alencar Oliveira1, Ruann Janser Soares de Castro ${ }^{1 *}$ (B) \\ ${ }^{1}$ Universidade Estadual de Campinas (UNICAMP), Faculdade de Engenharia de Alimentos, Departamento de \\ Ciência de Alimentos, Campinas/SP - Brasil
}

*Corresponding Author: Ruann Janser Soares de Castro, Universidade Estadual de Campinas (UNICAMP), Faculdade de Engenharia de Alimentos, Departamento de Ciência de Alimentos, Rua Monteiro Lobato, 80, CEP: 138083-862, Campinas/SP - Brasil, e-mail: ruann@unicamp.br

Cite as: Oliveira, I. M. A., \& Castro, R. J. S. (2020). Kefir fermentation as a bioprocess to improve lentils antioxidant properties: is it worthwhile?. Brazilian Journal of Food Technology, 23, e2019120. https://doi.org/10.1590/19816723.12019

\begin{abstract}
Kefir, a consortium of acetic and lactic bacteria and yeasts, is versatile for biotransformation of vegetable substrates and may improve their bioactive properties. Lentil is a legume rich in vitamins, minerals, complex carbohydrates and proteins, making it an excellent substrate for fermentation and obtaining bioactive molecules. We report the effect of different process variables on antioxidant properties of lentil extracts obtained using kefir as a biotransformation agent and experimental design. The results showed that the factors agitation (rpm) and incubation temperature exerted significant effects. Incubation temperature of $28{ }^{\circ} \mathrm{C}$ and agitation of $75 \mathrm{rpm}$ were the most suitable conditions for kefir fermentation and maximizing the antioxidant properties of the fermented lentils. The highest antioxidant activities for fermented products were $4128.39,35.87$ and $23.20 \mu \mathrm{mol}$ of Trolox equivalents per gram of sample ( $\mu \mathrm{moL} \mathrm{TE} \mathrm{g}^{-1}$ ) measured by Total Antioxidant Capacity, FRAP and DPPH-radical scavenging methods, respectively. Additionally, we detected that the initial fermentation times (in the first six hours) were enough to positively affect the antioxidant properties of the lentil extracts, reaching a percentage increase of up to $270 \%$ in the antioxidant activity of the fermented products in relation to those non-fermented samples.
\end{abstract}

Keywords: Lentils; Kefir; Fermentation; Bioactive compounds; Experimental design; Antioxidant properties.

\section{Resumo}

O kefir, um consórcio de bactérias acéticas e láticas, além de leveduras, mostra-se bastante versátil para adaptação a diversos meios de cultivo. A lentilha, por sua vez, é um grão rico em vitaminas, minerais, carboidratos complexos e proteínas, podendo ser um excelente substrato para fermentação e obtenção de moléculas bioativas. $O$ objetivo deste estudo foi avaliar o efeito de diferentes variáveis de processo sobre as propriedades antioxidantes de extratos de lentilhas obtidos utilizando kefir como agente de transformação. Os resultados mostraram que as variáveis de processo exerceram efeitos significativos sobre a obtenção de extratos de lentilhas biotransformados com alto teor de compostos antioxidantes. As atividades antioxidantes mais elevadas para os produtos fermentados foram 
4128,39, 35,87 e 23,20 $\mu \mathrm{mol}$ de equivalentes de Trolox por grama de amostra ( $\mu \mathrm{moL} \mathrm{TE} \mathrm{g}{ }^{-1}$ ), detectadas para os métodos Capacidade Antioxidante Total, FRAP e DPPH, respectivamente. Adicionalmente, também foi observado que os tempos iniciais de fermentação (nas primeiras seis horas) foram suficientes para afetar positivamente as propriedades antioxidantes dos extratos de lentilhas, atingindo um aumento percentual de até $270 \%$ na atividade antioxidante dos produtos fermentados em relação às amostras não fermentadas.

Palavras-chave: Lentilhas; Kefir; Fermentação; Compostos bioativos; Delineamento experimental; Propriedades antioxidantes.

\section{Introduction}

Kefir grains comprise the association of different groups of microorganisms including yeasts, acidic lactic and acetic bacteria in a matrix composed of polysaccharides and proteins (Gulitz et al., 2011; Amorim et al., 2019). The symbiotic activity of these microorganisms gives the kefir grains great versatility in the fermentation of different types of substrates, in addition to being an excellent source of probiotics with potential health benefits for the consumer (Prado et al., 2015; Reis et al., 2019). Although most scientific studies aim at obtaining fermented products of milk origin, kefir grains have shown great potential for application in the production of different functional beverages based on fruits and vegetables. This alternative route presents a very interesting appeal to offer new products to a growing market that includes vegan consumers, lactose intolerant and those allergic to dairy products (Fiorda et al., 2017).

Lentils (Lens culinaris L.) are one of the most produced and consumed legumes worldwide. These grains are rich in vitamins, minerals, complex carbohydrates as well as being excellent sources of proteins and containing low lipid contents (Wang \& Toews, 2011; Zare et al., 2012; Agil et al., 2013; Bautista-Expósito et al., 2018). The presence of phytochemicals, such as phenolic acids, flavonoids and other related phenolic compounds can also be pointed out as a notable characteristic of these grains, since these substances are strongly associated with some biological properties, such as antioxidant activity (Zhang et al., 2015; Fiorda et al., 2017).

Biotransformation of vegetables, such as their fermentation, is a recognized strategy to improve the nutritional and biological properties of these substrates. The main effects of fermentation on the biological properties of legumes are related to the bioconversion of conjugated forms of phenolic compounds to their soluble forms with consequent change in the profile of bioactive substances and increase of related biological activities (Agil et al., 2013; Torino et al., 2013; Simsek et al., 2014; Tu et al., 2019).

Thus, this work reported an optimization study on the cultivation of kefir grains by submerged fermentation using lentils as substrate. The extracts obtained from non-fermented and fermented lentils were comparatively analyzed for their antioxidant properties. The process developed in this work presents an alternative way to obtain a fermented beverage using kefir grains with improved antioxidant properties.

\section{Material and methods}

\subsection{Reagents}

The reagents Folin and Ciocalteau's phenol reagent, sodium carbonate, Trolox (6-hydroxy-2,5,7,8tetramethlchroman-2-carboxylic acid), DPPH (2,2-diphenyl-1-picrylhydrazyl), ABTS (2,2'-azinobis-3ethyl-benzthiazoline-6-sulfonic acid), sodium nitrite, aluminum chloride, sodium hydroxide; vanillin, 2,4,6Tri(2-pyridyl)-s-triazine (TPTZ) and hydrated iron chloride were purchased from Sigma Aldrich. All the other reagents used in the experiments were of analytical grade. 


\subsection{Preparation of the lentils flour as substrate for submerged fermentation}

We used fresh lentil, purchased from a local market (Campinas, Sao Paulo, Brazil), to prepare the lentil flour and used for fermentation process. The lentil grains were crushed in a blender, frozen and freeze-dried. The powdered product obtained was stored under refrigeration to use as substrate for submerged fermentation.

\subsection{Kefir grains preparation, pre-inoculum and inoculum production}

Kefir grains were obtained from a private household located in Campinas (Sao Paulo, Brazil). The cultivation of the kefir grains was performed using $250 \mathrm{~mL}$ Erlenmeyer flasks containing $100 \mathrm{~mL}$ of $10 \%(\mathrm{w} / \mathrm{v})$ sucrose solution. The flasks containing the culture medium were sterilized and the kefir grains were inoculated at an initial concentration of $10 \% \mathrm{w} / \mathrm{v}$ and incubated at $30^{\circ} \mathrm{C}$ with renewal of culture medium every $24 \mathrm{~h}$. This procedure was carried out for 14 days to reach the amount of biomass required for the fermentation processes. The biomass produced over the days was frozen, lyophilized and stored for use as a pre-inoculum for fermentation. For each test, the lyophilized kefir grains were cultured as described previously for $96 \mathrm{~h}$ and then used as inoculum for submerged fermentation.

\subsection{Submerged fermentation of lentil flour}

For the fermentation process, $50 \mathrm{~mL}$ of a $10 \%(\mathrm{w} / \mathrm{v})$ sucrose solution containing lentil flour at $5 \%(\mathrm{w} / \mathrm{v})$ was distributed in $125 \mathrm{~mL}$ Erlenmeyer flasks and sterilized at $121{ }^{\circ} \mathrm{C}$ for $15 \mathrm{~min}$. For each assay, the previously activated kefir grains were inoculated at an initial concentration of $5 \%(\mathrm{w} / \mathrm{v})$ in the culture media and incubated for 24 and $48 \mathrm{~h}$. The control tests were carried out under the same fermentation conditions without addition of the inoculum and evaluated comparatively with their respective fermented samples.

Finally, the fermented media and controls were subjected to centrifugation and filtration through a filter membrane (Whatman ${ }^{\circledR}$ qualitative filter paper $\mathrm{n}^{\circ} 1$ ) to obtain an extract free of any solid material. The supernatants were frozen and used as extracts to evaluate the antioxidant properties.

\subsection{Effects of the cultivation parameters on antioxidant properties of lentil extracts}

We evaluated the effects of kefir grains culture parameters, including agitation (rpm) and incubation temperature using a Central Composite Rotatable Design (CCRD) at different levels (Table 1). The submerged fermentation of lentil flour was performed as previously described. 
Table 1. Matrix of the CCRD used to study the effects of the independent variables agitation and incubation temperature on antioxidant properties of the non-fermented and fermented extracts from lentils using kefir grains.

\begin{tabular}{|c|c|c|c|c|c|c|c|c|c|c|}
\hline \multirow[b]{2}{*}{ Run } & \multicolumn{3}{|c|}{ Independent Variables } & \multicolumn{7}{|c|}{ Total Antioxidant Capacity $\left(\mu \mathrm{mol}\right.$ TE $\left.\mathrm{g}^{-1}\right)$} \\
\hline & $\mathbf{x}_{1} /$ Agitation (rpm) & \multicolumn{2}{|c|}{$\mathbf{x}_{2} /$ Temperature $\left({ }^{\circ} \mathrm{C}\right)$} & \multicolumn{2}{|c|}{$\begin{array}{l}\text { Non-fermented } \\
(24 \mathrm{~h})\end{array}$} & \multicolumn{2}{|c|}{ Fermented (24 h) } & \multicolumn{2}{|c|}{$\begin{array}{c}\text { Non-fermented } \\
(48 \mathrm{~h})\end{array}$} & Fermented (48 h) \\
\hline 1 & $-1(25)$ & \multicolumn{2}{|l|}{$-1(22.3)$} & \multicolumn{2}{|c|}{$4215.73 \pm 139.94$} & \multicolumn{2}{|c|}{$1253.71 \pm 52.06$} & \multicolumn{2}{|c|}{$1970.45 \pm 59.38$} & $1697.62 \pm 88.78$ \\
\hline 2 & $+1(128)$ & \multicolumn{2}{|l|}{$-1(22.3)$} & \multicolumn{2}{|c|}{$2280.21 \pm 49.61$} & \multicolumn{2}{|c|}{$1725.65 \pm 162.93$} & \multicolumn{2}{|c|}{$3755.07 \pm 176.99$} & $1089.55 \pm 119.55$ \\
\hline 3 & $-1(25)$ & \multicolumn{2}{|l|}{$+1(33.7)$} & \multicolumn{2}{|c|}{$2850.06 \pm 149.71$} & \multicolumn{2}{|c|}{$1525.71 \pm 48.95$} & \multicolumn{2}{|c|}{$3236.41 \pm 170.65$} & $2700.55 \pm 129.03$ \\
\hline 4 & $+1(128)$ & \multicolumn{2}{|l|}{$+1(33.7)$} & \multicolumn{2}{|c|}{$2966.84 \pm 52.52$} & \multicolumn{2}{|c|}{$1184.39 \pm 117.95$} & \multicolumn{2}{|c|}{$5345.19 \pm 114.89$} & $297.81 \pm 111.68$ \\
\hline 5 & $-1.41(0)$ & \multicolumn{2}{|l|}{$0(28)$} & \multicolumn{2}{|c|}{$3133.28 \pm 139.87$} & \multicolumn{2}{|c|}{$2290.07 \pm 99.72$} & $3129.11 \pm 140$ & & $4143.40 \pm 18.02$ \\
\hline 6 & $+1.41(150)$ & $0(28)$ & & 2375.0 & \pm 263.18 & & $5.26 \pm 91.19$ & $4681.31 \pm 84$ & & $1109.57 \pm 11.70$ \\
\hline 7 & $0(75)$ & $-1.41(20)$ & & 2472.4 & \pm 241.99 & & $.50 \pm 250.44$ & $2731.39 \pm 96$ & & $2231.37 \pm 30.83$ \\
\hline 8 & $0(75)$ & $+1.41(36)$ & & 3861.2 & \pm 220.46 & & $.02 \pm 151.49$ & $4426.91 \pm 91$ & & $1257.71 \pm 91.00$ \\
\hline 9 & $0(75)$ & $0(28)$ & & 3779.7 & \pm 188.50 & & $1.36 \pm 71.07$ & $4718.85 \pm 235$ & & $2484.10 \pm 124.20$ \\
\hline 10 & $0(75)$ & $0(28)$ & & 3662.5 & \pm 183.12 & & $4.52 \pm 66.23$ & $4492.50 \pm 224$ & & $2569.68 \pm 128.48$ \\
\hline 11 & $0(75)$ & $0(28)$ & & 4003.7 & \pm 200.18 & & $7.77 \pm 65.88$ & $4799.61 \pm 239$ & & $2766.37 \pm 138.31$ \\
\hline & & DPPH-radical scaveng & $\operatorname{lng}(\mu$ & TE $\left.g^{-1}\right)$ & & & & FRAP $(\mu \mathrm{n}$ & ol TE $\left.g^{-1}\right)$ & \\
\hline Run & $\begin{array}{c}\text { Non-fermented } \\
(24 \mathrm{~h})\end{array}$ & Fermented (24 h) & Non- & iented & Fermen & & $\begin{array}{c}\text { Non-fermented } \\
(24 \mathrm{~h})\end{array}$ & Fermented (24 h) & $\begin{array}{c}\text { Non-fermented } \\
(48 \mathrm{~h})\end{array}$ & Fermented (48 h) \\
\hline 1 & $11.10 \pm 1.47$ & $10.70 \pm 0.99$ & & 2.00 & 9.88 & & $15.45 \pm 2.87$ & $26.27 \pm 2.35$ & $10.98 \pm 0.40$ & $35.69 \pm 1.50$ \\
\hline 2 & $14.83 \pm 0.76$ & $11.44 \pm 0.86$ & 13. & 1.90 & 10.25 & & $14.42 \pm 2.26$ & $22.44 \pm 5.67$ & $18.12 \pm 1.38$ & $26.22 \pm 4.29$ \\
\hline 3 & $16.07 \pm 0.04$ & $13.04 \pm 0.35$ & 11. & 1.97 & 13.40 & & $16.89 \pm 1.33$ & $26.26 \pm 3.51$ & $10.87 \pm 1.80$ & $37.58 \pm 4.62$ \\
\hline 4 & $14.23 \pm 0.47$ & $11.57 \pm 1.79$ & 15. & 1.21 & 11.72 & & $16.72 \pm 2.23$ & $26.73 \pm 5.76$ & $18.10 \pm 0.93$ & $32.41 \pm 5.47$ \\
\hline 5 & $16.08 \pm 0.61$ & $10.84 \pm 0.18$ & 12. & 1.57 & 12.07 & & $16.93 \pm 0.30$ & $25.95 \pm 4.90$ & $13.33 \pm 0.53$ & $37.53 \pm 6.11$ \\
\hline 6 & $13.46 \pm 0.24$ & $11.23 \pm 1.39$ & 12. & 1.93 & 14.42 & & $16.42 \pm 1.48$ & $27.51 \pm 4.84$ & $13.95 \pm 0.71$ & $37.31 \pm 6.23$ \\
\hline 7 & $14.43 \pm 1.31$ & $10.58 \pm 2.20$ & 12. & 0.31 & 12.76 & & $16.43 \pm 1.30$ & $21.30 \pm 4.95$ & $16.67 \pm 1.94$ & $38.51 \pm 5.30$ \\
\hline 8 & $15.93 \pm 1.47$ & $11.63 \pm 0.22$ & 13. & 0.51 & 17.54 & & $18.02 \pm 1.44$ & $26.50 \pm 3.99$ & $17.11 \pm 1.23$ & $49.78 \pm 5.72$ \\
\hline 9 & $14.28 \pm 0.01$ & $9.97 \pm 1.04$ & 10. & 0.55 & 13.37 & & $17.62 \pm 0.82$ & $27.20 \pm 3.10$ & $17.54 \pm 0.85$ & $44.23 \pm 4.47$ \\
\hline 10 & $14.92 \pm 0.72$ & $10.66 \pm 0.34$ & 10. & 0.14 & 13.68 & & $20.16 \pm 1.17$ & $31.81 \pm 3.75$ & $17.69 \pm 0.88$ & $56.82 \pm 1.85$ \\
\hline 11 & $14.52 \pm 0.68$ & $10.28 \pm 0.75$ & 10. & 0.01 & 13.09 & & $19.31 \pm 0.01$ & $28.22 \pm 1.48$ & $18.04 \pm 0.92$ & $51.66 \pm 3.22$ \\
\hline
\end{tabular}


We used second order equations to define models for the experimental design as describe below (Equation 1):

$$
Y=\beta_{0}+\sum_{i=1}^{n} \beta_{i} x_{i}+\sum_{i=1}^{n-1} \sum_{j=i+1}^{n} \beta_{i j} x_{i} x_{j}
$$

where $\mathrm{Y}$ represents the estimated response by the model, $\mathrm{i}$ and $\mathrm{j}$ corresponds to the variation of 1 for the variables number $(n) ; \beta_{0}$ is the mean value; $\beta_{\mathrm{i}}$ and $\beta_{\mathrm{ij}}$ represent the linear and quadratic coefficients, respectively; $x i$ and $x j$ are the coded independent variables.

The multiple correlation coefficient $\left(\mathrm{R}^{2}\right)$ and Fisher's test (variance analysis - ANOVA) were used to verify the statistical adequacy of the proposed coded models to the real points. The software Statistica 13.3 from TIBCO Software Inc. Company (Palo Alto, California, USA) was used on the experimental design, to analyze the data and generate the models.

\subsection{Effects of the fermentation time on antioxidant properties of lentil extracts}

We evaluated the effect of the fermentation time on antioxidant properties of lentil extracts upon selecting the culture conditions that allowed the production of fermented products with high antioxidant activities from the analysis of CCRD. The fermentation process was carried out in the same way as previously described with fermentation times adjusted to $0,2,4,6,8,10$ and $12 \mathrm{~h}$. Control assays (non-fermented samples) were also performed without the addition of kefir grains. We performed antioxidant activity assays for all samples, in addition to quantification of total phenolic compounds and $\mathrm{pH}$ determination.

\subsection{Determination of antioxidant properties}

\subsubsection{Total antioxidant capacity}

Total antioxidant capacity of the extracts from non-fermented and fermented lentils was performed according to the method described by Prieto et al. (1999). An aliquot of $0.1 \mathrm{~mL}$ of the lentil extracts at $0.30 \mathrm{mg} \mathrm{mL}^{-1}$ (non-fermented samples) and $0.50 \mathrm{mg} \mathrm{mL}^{-1}$ (fermented samples), was mixed with $1.0 \mathrm{~mL}$ of the reagent solution containing $0.6 \mathrm{M}$ sulphuric acid, $28 \mathrm{mM}$ sodium phosphate and $4 \mathrm{mM}$ ammonium molybdate. The reaction mixtures were then incubated at $90{ }^{\circ} \mathrm{C}$ and kept in the dark for $90 \mathrm{~min}$. The samples were cooled to room temperature and the absorbance was measured at $695 \mathrm{~nm}$. We used an appropriate control prepared with $1.0 \mathrm{~mL}$ of the reagent solution and $0.1 \mathrm{~mL}$ distilled water. A standard curve was prepared with different concentrations of Trolox $(0$ to $2000 \mu \mathrm{M})$ and the results were expressed as $\mu \mathrm{mol}$ of Trolox Equivalents per gram of lentil flour in culture medium $\left(\mu \mathrm{mol} \mathrm{TE} \mathrm{g}^{-1}\right)$.

\subsubsection{Determination of DPPH-radical scavenging activity}

The DPPH-radical (2,2-diphenyl-1-picrylhydrazyl) scavenging activity of the lentil extracts was determined as described by Bougatef et al. (2009). A $500 \mu \mathrm{L}$ aliquot of each sample at $2 \mathrm{mg} \mathrm{mL}^{-1}$ was mixed with $500 \mu \mathrm{L} 99.5 \%$ ethanol and $125 \mu \mathrm{L} 0.02 \% \mathrm{DPPH}$ in $99.5 \%$ ethanol. The mixture was then kept at room temperature, in the dark for $60 \mathrm{~min}$, and the reduction of the DPPH radical was measured at $517 \mathrm{~nm}$ using a UV-visible spectrophotometer (Beckman DU 70 spectrophotometer, Beckman-Coulter, Inc., Fullerton, CA, USA). The control reaction was performed in the same manner, except that distilled water was used instead of sample. A standard curve was prepared with different concentrations of Trolox $(0-50 \mu \mathrm{M})$ and the results were expressed as $\mu \mathrm{mol} \mathrm{TE} \mathrm{g}^{-1}$. 


\subsubsection{Measurement of Ferric Reducing/Antioxidant Power (FRAP) assay}

A FRAP assay was performed according to Benzie \& Strain (1996) with modifications proposed by Wiriyaphan et al. (2012). FRAP reagent was prepared by mixing $2.5 \mathrm{~mL}$ of $10 \mathrm{mM}$ TPTZ solution in $40 \mathrm{mM}$ $\mathrm{HCl} ; 25 \mathrm{~mL}$ of $0.3 \mathrm{M}$ acetate buffer (pH 3.6), and $2.5 \mathrm{~mL}$ of $20 \mathrm{mM} \mathrm{FeCl}{ }_{3} \cdot 6 \mathrm{H}_{2} \mathrm{O}$ solution. Aliquots of $100 \mu \mathrm{L}$ of lentil extracts at $2 \mathrm{mg} \mathrm{mL}^{-1}$ (non-fermented samples) and $1 \mathrm{mg} \mathrm{mL}^{-1}$ (fermented samples), blank or Trolox $(5-250 \mu \mathrm{M})$ were mixed with $1 \mathrm{~mL}$ of fresh FRAP reagent. The reaction mixture was then incubated at $37{ }^{\circ} \mathrm{C}$ for $15 \mathrm{~min}$ in a water bath. Absorbance of each reaction was monitored at $593 \mathrm{~nm}$. Results were expressed as $\mu \mathrm{mol} \mathrm{TE} \mathrm{g}^{-1}$.

\subsection{Total phenolic compounds}

The total phenolic content was determined by the reaction with the Folin-Ciocalteau reagent, according to the method described by Roesler et al. (2007). Aliquots of $0.5 \mathrm{~mL}$ of each sample were mixed with $2.5 \mathrm{~mL}$ of Folin-Ciocalteau aqueous solution $(10 \% \mathrm{v} / \mathrm{v})$ and $2.0 \mathrm{~mL}$ of $\mathrm{Na}_{2} \mathrm{CO}_{3}$ solution $(7.5 \% \mathrm{w} / \mathrm{v})$. The reaction mixtures were incubated at $50^{\circ} \mathrm{C}$ for $5 \mathrm{~min}$ and the absorbance was determined at $760 \mathrm{~nm}$. Quantification of the phenolic compounds was performed using a calibration curve of gallic acid $\left(0-0.10 \mathrm{mg} \mathrm{mL}^{-1}\right)$ and the results were expressed as $\mathrm{mg}$ of gallic acid equivalent per gram of lentil flour in culture medium (mg GAE g$\left.{ }^{-1}\right)$.

\subsection{Calculations and statistics}

The results were statistically analyzed according to the Tukey test and Pearson correlation coefficient, using the software Minitab ${ }^{\circledR} 18$ from Minitab Inc. (USA). The values were expressed as the arithmetic mean $(\mathrm{n}=3)$ and were considered statistically different or correlated when the $p \leq 0.05$.

\section{Results and discussion}

\subsection{Effects of the process parameters on the antioxidant properties of lentil extracts using experimental design (CCRD)}

The results obtained from CCRD for the different runs showed that the independent variables (agitation and incubation temperature) had interesting effects on the fermentation process, with great variation of the antioxidant activities according to each culture condition (Table 1). For example, the lentil extracts obtained

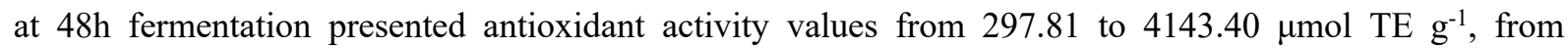
9.88 to $17.54 \mu \mathrm{mol} \mathrm{TE} \mathrm{g}^{-1}$ and from 26.22 to $56.82 \mu \mathrm{mol} \mathrm{TE} \mathrm{g}^{-1}$ when measured by Total Antioxidant Activity, DPPH-radical scavenging and FRAP methods, respectively (Table 1).

The analysis of effects of the independent variables allows to determine whether the factors studied had a significant or non-significant effect, which may be positive or negative. Regression coefficients that indicate the magnitude and significance of these factors are used to construct equations and predict experimental responses in different growing conditions. In addition to the effects assessment, analysis of variance (ANOVA) should be performed to verify the statistical adequacy of the experimental results. The data presented in Table 2 show the values of $F$ calculated and $F$ tabulated, $R^{2}$ and $p$-value for each response. The models with $R^{2}$ below $0.75, \mathrm{~F}$ calculated lower than $\mathrm{F}$ tabulated and $p$-values greater than 0.10 were considered unsatisfactory. As such, four models were generated, allowing the construction of four response surfaces for Total Antioxidant Capacity (Figure 1) and for FRAP (Figure 2). The results for DPPH-radical scavenging did not generate significant models. 
Table 2. Analysis of variance (ANOVA) including Fisher's test ( $F$ calculated and $F$ tabulated), multiple correlation coefficient $\left(\mathrm{R}^{2}\right)$ and probability values ( $p$-value) for the antioxidant properties of the non-fermented and fermented extracts from lentils using kefir grains.

\begin{tabular}{|c|c|c|c|c|c|}
\hline Responses & Samples & $F$ calculated & $F$ tabulated & $R^{2}$ & $p$-value \\
\hline \multirow{4}{*}{$\begin{array}{c}\text { Total Antioxidant } \\
\text { Capacity } \\
\left(\mu \mathrm{mol} \mathrm{TE} \mathrm{g}^{-1}\right)\end{array}$} & Non-fermented (24 h) & 4.27 & 3.07 & 0.65 & 0.052 \\
\hline & Fermented (24 h) & 3.67 & 3.18 & 0.71 & 0.076 \\
\hline & Non-fermented $(48 \mathrm{~h})$ & 30.15 & 3.18 & 0.95 & $<0.001$ \\
\hline & Fermented (48 h) & 7.80 & 3.07 & 0.77 & 0.012 \\
\hline \multirow{4}{*}{$\begin{array}{l}\text { DPPH-radical } \\
\text { scavenging } \\
\left(\mu \mathrm{mol} \mathrm{TE} \mathrm{g}^{-1}\right)\end{array}$} & Non-fermented $(24 \mathrm{~h})$ & 7.42 & 3.11 & 0.65 & 0.015 \\
\hline & Fermented (24 h) & 3.57 & 3.46 & 0.31 & 0.096 \\
\hline & Non-fermented $(48 \mathrm{~h})$ & 3.39 & 3.07 & 0.59 & 0.083 \\
\hline & Fermented (48 h) & 5.33 & 3.46 & 0.40 & 0.050 \\
\hline \multirow{4}{*}{$\operatorname{FRAP}\left(\mu \mathrm{mol}\right.$ TE $\left.\mathrm{g}^{-1}\right)$} & Non-fermented (24 h) & 4.93 & 3.18 & 0.77 & 0.042 \\
\hline & Fermented $(24 \mathrm{~h})$ & 6.55 & 3.11 & 0.62 & 0.021 \\
\hline & Non-fermented $(48 \mathrm{~h})$ & 8.42 & 3.11 & 0.68 & 0.011 \\
\hline & Fermented (48 h) & 4.82 & 3.18 & 0.76 & 0.044 \\
\hline
\end{tabular}
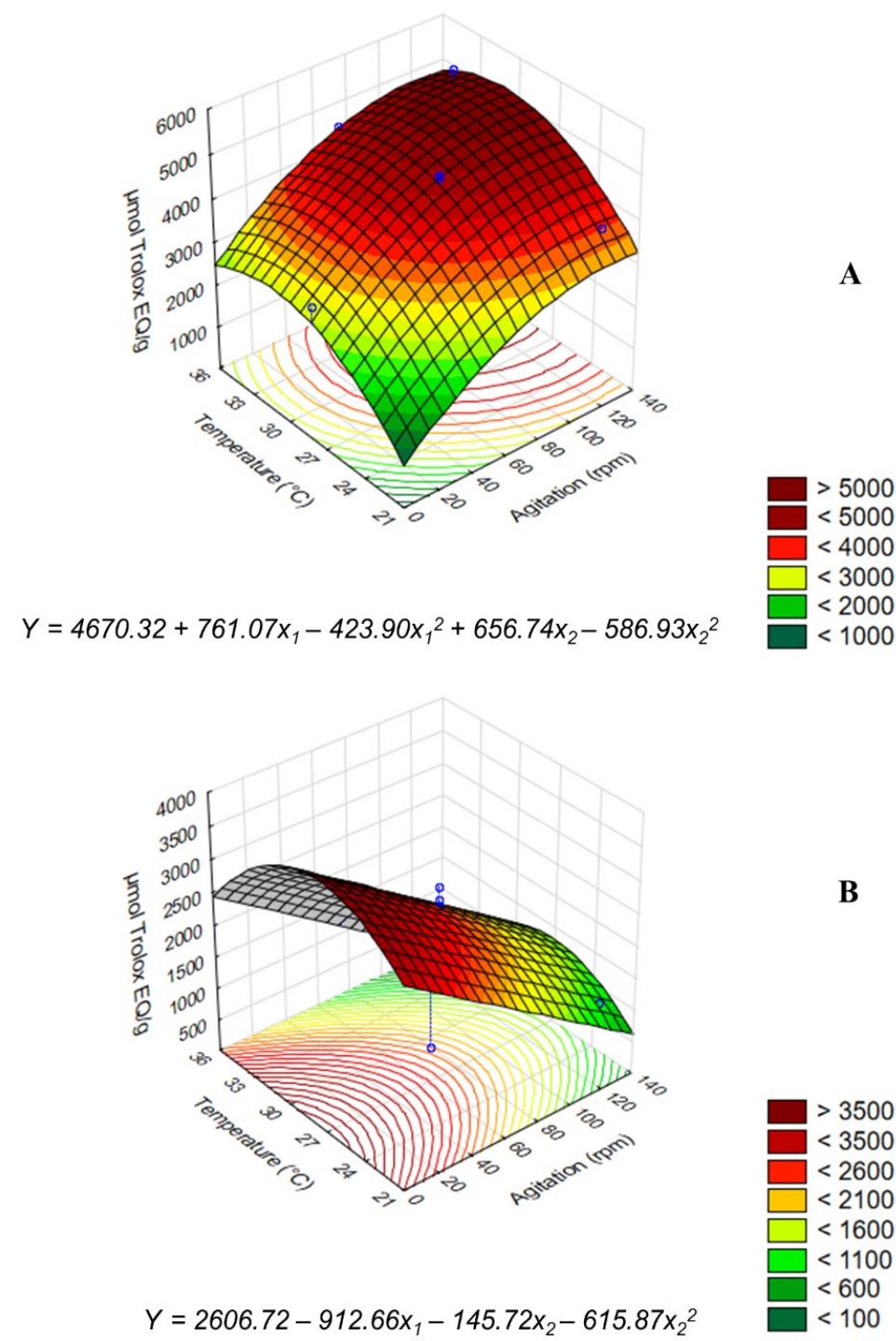

Figure 1. Response surfaces and models equations for antioxidant activity measured by the Total Antioxidant Capacity method for lentil extracts obtained from non-fermented samples (A) after $48 \mathrm{~h}$ incubation and for the fermented samples

(B) after $48 \mathrm{~h}$ fermentation in function of the significant parameters $(p \leq 0.10)$. The coded values in the equations represent the independent variables and their interactions: $\mathrm{x}_{1}=$ Agitation $(\mathrm{rpm})$ and $\mathrm{x}_{2}=$ Temperature $\left({ }^{\circ} \mathrm{C}\right)$. 

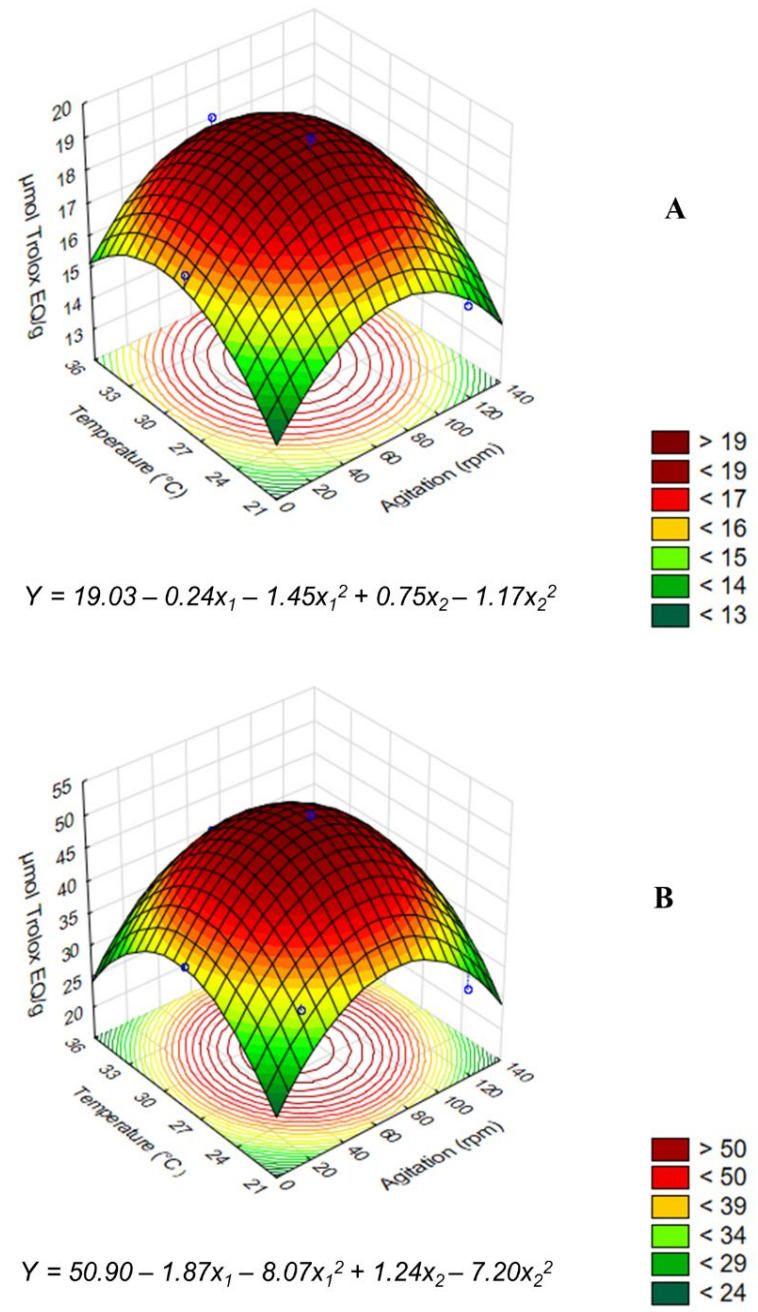

Figure 2. Response surfaces and models equations for antioxidant activity measured by FRAP method for lentil extracts obtained from non-fermented samples (A) after $24 \mathrm{~h}$ incubation and for the fermented samples (B) after $48 \mathrm{~h}$ fermentation in function of the significant parameters $(p \leq 0.10)$. The coded values in the equations represent the independent variables and their interactions: $\mathrm{x}_{1}=$ Agitation $(\mathrm{rpm})$ and $\mathrm{x}_{2}=$ Temperature $\left({ }^{\circ} \mathrm{C}\right)$.

When analyzing the responses with significant effects $(p \leq 0.10)$, we observe that incubation temperature and agitation, promoted considerable changes in the antioxidant activity of the lentil extracts. For the non-fermented samples incubated for $48 \mathrm{~h}$ and evaluated by the Total Antioxidant Capacity method, it was observed that the linear terms of agitation and temperature were significant $(p \leq 0.10)$ and positive in the response, whereas the quadratic terms of these same variables were significant $(p \leq 0.10)$ and negative (Figure 1A). This evaluation allowed to conclude that the increase in the level of the evaluated parameters promoted an increase in the recovery of antioxidant compounds to a certain point, from which there is reduction of the activity. For the lentil extract produced under $48 \mathrm{~h}$ fermentation, all the significant effects observed were negative, indicating that the increase in the values of agitation and temperature promoted a decrease in the antioxidant properties of the products obtained (Figure 1B).

For the antioxidant activities of the lentil extracts produced after incubation for $24 \mathrm{~h}$ (non-fermented lentils) measured by the FRAP method, the linear and quadratic terms of the independent variables were significant $(p \leq 0.10)$, detecting negative effect for agitation and positive and negative effects for the linear and quadratic terms of temperature, respectively (Figure 2A). In this case, the evaluation indicated that any increase in the agitation level resulted in a decrease in the ferric ion reducing antioxidant power (FRAP), 
while the increase in temperature exerted an initial positive and then negative effect. For the fermented lentil extract obtained at $48 \mathrm{~h}$, the same behavior described above was observed (Figure 2B).

By evaluating the response surfaces, we infer that temperatures in the range from 28 to $30^{\circ} \mathrm{C}$ resulted in lentil extracts with higher antioxidant properties (Figure 1 and Figure 2). For the fermented products, the results are in agreement with previous studies already conducted with kefir grains. Viana et al. (2017) used $28{ }^{\circ} \mathrm{C}$ as incubation temperature in a fermentative process using kefir in order to produce an apple-based kefir vinegar and obtained a yield of $79 \%$ acetic acid. Fiorda et al. (2016a) showed that an incubation temperature of $30{ }^{\circ} \mathrm{C}$ was the most adequate for high growth of kefir grains. Thus, the temperature range observed as being the most suitable for obtaining compounds with antioxidant properties in our study, is also favorable for the growth and metabolism of kefir microorganisms which is also due to the high content and mesophilic character of lactic and acetic bacteria as well the yeasts present in the grain (Fiorda et al., 2016a).

The agitation effects on antioxidant properties of the lentil extracts were different for each method. When the lentil extracts were obtained under low agitation conditions for the $48 \mathrm{~h}$ fermentation time, the Total Antioxidant Capacity was higher. Meanwhile, for the FRAP method, the best results were obtained for the lentil extracts produced at $75 \mathrm{rpm}$ agitation for non-fermented and fermented samples (Figure 2). Based on these observations, the culture conditions of the central points from CCRD $\left(75 \mathrm{rpm}\right.$ agitation and $28{ }^{\circ} \mathrm{C}$ as incubation temperature) were selected to study the effects of the incubation time on the antioxidant properties of the lentil extracts.

\subsection{Effects of the incubation time on the antioxidant properties of lentil extracts}

The variation of the antioxidant properties of the lentil extracts as a function of the incubation time was performed in order to verify that shorter fermentation times would exert positive effects on the biological activity of the fermented products, since the observed effects in most of the CCRD runs were negative after 24 and $48 \mathrm{~h}$ fermentation. In this case, the analysis of total phenolic compounds was also performed for each incubation time to study possible correlations among the results. Table 3 shows the results obtained for each test as well as the percentage variation calculated as a function of the values observed for the fermented samples in relation to their respective non-fermented samples. The correlation analyzes using the Pearson coefficient showed that there was no significant correlation $(p \geq 0.05)$ between the antioxidant activity and the phenolic compounds content.

Table 3. Antioxidant properties and total phenolic compounds for lentil extracts obtained from non-fermented samples and fermented with kefir at $28^{\circ} \mathrm{C}$ and $75 \mathrm{rpm}$ agitation during fermentation kinetics.

\begin{tabular}{|c|c|c|c|c|c|c|}
\hline \multirow{2}{*}{$\begin{array}{l}\text { Incubation } \\
\text { time (h) }\end{array}$} & \multicolumn{3}{|c|}{ Total Antioxidant Capacity $\left(\mu \mathrm{mol}\right.$ TE $\left.\mathrm{g}^{-1}\right)$} & \multicolumn{3}{|c|}{ FRAP $\left(\mu \mathrm{mol} \mathrm{TE} \mathrm{g}^{-1}\right)$} \\
\hline & Non-fermented & Fermented & $\begin{array}{c}\text { Variation } \\
(\%) \\
\end{array}$ & $\begin{array}{c}\text { Non- } \\
\text { fermented }\end{array}$ & Fermented & $\begin{array}{c}\text { Variation } \\
(\%)\end{array}$ \\
\hline 2 & $1259.56 \pm 130.33^{\mathrm{a}}$ & $\begin{array}{c}4128.39 \pm \\
139.50^{\mathrm{b}}\end{array}$ & 227.76 & $17.61 \pm 0.22^{\mathrm{a}}$ & $35.69 \pm 3.89^{\mathrm{b}}$ & 102.63 \\
\hline 4 & $995.30 \pm 122.62^{\mathrm{a}}$ & $\begin{array}{c}3690.98 \pm \\
172.80^{\mathrm{b}} \\
\end{array}$ & 270.84 & $17.44 \pm 2.36^{\mathrm{a}}$ & $35.87 \pm 2.11^{\mathrm{b}}$ & 105.64 \\
\hline 6 & $1360.03 \pm 34.05^{\mathrm{a}}$ & $3864.39 \pm 13.76^{\mathrm{b}}$ & 184.14 & $19.31 \pm 0.34^{\mathrm{a}}$ & $28.57 \pm 2.30^{b}$ & 47.93 \\
\hline 8 & $1181.84 \pm 122.14^{\mathrm{a}}$ & $3158.73 \pm 62.09^{b}$ & 167.27 & $21.07 \pm 0.31^{\mathrm{a}}$ & $28.59 \pm 3.59^{b}$ & 35.73 \\
\hline 10 & $1522.31 \pm 38.05^{\mathrm{a}}$ & $3528.83 \pm 82.94^{\mathrm{b}}$ & 131.81 & $23.28 \pm 2.28^{\mathrm{a}}$ & $33.87 \pm 0.83^{b}$ & 45.48 \\
\hline 12 & $1689.13 \pm 43.79^{\mathrm{a}}$ & $4045.31 \pm 71.27^{\mathrm{b}}$ & 139.49 & $31.65 \pm 1.32^{\mathrm{a}}$ & $30.16 \pm 2.82^{\mathrm{a}}$ & -4.74 \\
\hline \multirow{2}{*}{$\begin{array}{c}\text { Incubation } \\
\text { time (h) }\end{array}$} & \multicolumn{3}{|c|}{ DPPH-radical Scavenging $\left(\mu \mathrm{mol} \mathrm{TE} \mathrm{g}^{-1}\right)$} & \multicolumn{3}{|c|}{ Total Phenolic Content (mg GAE $\mathrm{g}^{-1}$ ) } \\
\hline & Non-fermented & Fermented & $\begin{array}{c}\text { Variation } \\
(\%) \\
\end{array}$ & $\begin{array}{c}\begin{array}{c}\text { Non- } \\
\text { fermented }\end{array} \\
\end{array}$ & Fermented & $\begin{array}{c}\text { Variation } \\
\mathbf{( \% )} \\
\end{array}$ \\
\hline 2 & $21.97 \pm 0.10^{\mathrm{a}}$ & $23.20 \pm 0.17^{\mathrm{a}}$ & 5.61 & $7.53 \pm 0.29^{\mathrm{a}}$ & $7.98 \pm 0.41 \mathrm{a}$ & 5.98 \\
\hline 4 & $21.53 \pm 0.57^{\mathrm{a}}$ & $23.02 \pm 0.40^{\mathrm{a}}$ & 6.91 & $8.16 \pm 0.13^{a}$ & $9.94 \pm 0.42 b$ & 21.77 \\
\hline 6 & $19.88 \pm 0.12^{\mathrm{a}}$ & $21.42 \pm 0.20^{\mathrm{b}}$ & 7.72 & $7.17 \pm 0.51^{\mathrm{a}}$ & $9.58 \pm 0.44 b$ & 33.64 \\
\hline 8 & $21.95 \pm 0.17^{\mathrm{a}}$ & $20.24 \pm 0.20^{\mathrm{b}}$ & -7.80 & $7.21 \pm 0.30^{\mathrm{a}}$ & $7.87 \pm 0.61 \mathrm{a}$ & 9.23 \\
\hline 10 & $20.86 \pm 0.23^{\mathrm{a}}$ & $19.64 \pm 0.45^{\mathrm{a}}$ & -5.83 & $7.94 \pm 0.30^{\mathrm{a}}$ & $6.49 \pm 0.45 b$ & -18.33 \\
\hline 12 & $21.12 \pm 0.39^{\mathrm{a}}$ & $17.95 \pm 0.48^{b}$ & -14.98 & $7.95 \pm 0.57^{\mathrm{a}}$ & $6.51 \pm 0.48 b$ & -18.03 \\
\hline
\end{tabular}


Results are expressed as mean $(n=3) \pm$ standard deviation and those with different letters in the same line for determination in each antioxidant method were considered statistically different at $p \leq 0.05$. The variation

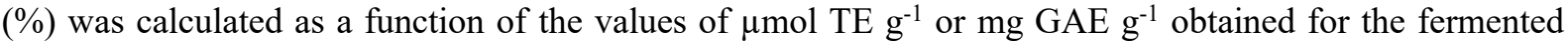
samples in relation to their respective non-fermented sample.

The highest values of antioxidant activity and total phenolic compounds for fermented products were detected in the first incubation times, especially in the first $6 \mathrm{~h}$ of the process. This knowledge indicates fermentations with kefir for short periods as a good alternative, since time is an important parameter related to the process cost. In addition, high antioxidant activity percentage gains for the extracts obtained from fermented lentils in comparison to their respective non-fermented samples were detected in Total Antioxidant Capacity and FRAP methods, reaching maximum increases of $270 \%$ and $105 \%$, respectively, after $4 \mathrm{~h}$ of fermentation (Table 3).

The increase in antioxidant properties of lentil extracts may be linked to the biotransformation of macromolecules that carry these possible antioxidants, but in an inactive form, which would be bound to the substrate and without activity. Gunenc et al. (2017) suggested that fermentation with kefir is capable of hydrolyzing complex lentil polysaccharides and releasing phenolic compounds, increasing antioxidant activity. These phenolic compounds are commonly associated with fiber and proteins, naturally present in lentils (Gunenc et al., 2017).

The variation of the $\mathrm{pH}$ values in the lentil extracts was monitored in function of the incubation time and the results expressed in Figure 3 confirmed the intense action of the microorganisms in the culture medium from the beginning of the fermentation process.

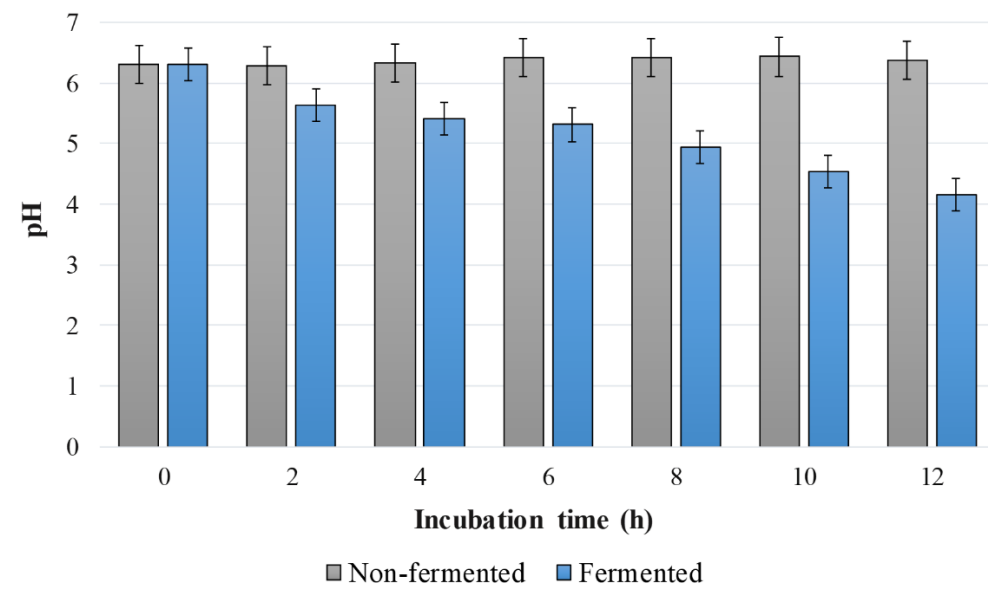

Figure 3. Variation of $\mathrm{pH}$ during incubation of non-fermented and fermented by kefir culture media using lentil flour as substrate.

By evaluating the process kinetics performed, we verified the rapid and continuous reduction of the $\mathrm{pH}$ of the medium promoted by the fermentation with the kefir grains, while the samples that were not fermented presented stable $\mathrm{pH}$ values for all incubation times evaluated (Figure 3). This behavior corroborates with Fiorda et al. (2016b), who evaluated the fermentation with kefir in soy drink, milk and bovine colostrum. In all cases, the highest $\mathrm{pH}$ variation occurred during the first $24 \mathrm{~h}$ fermentation. This decrease is due to the production of organic acids, ethanol, carbon dioxide and other volatile substances (Fiorda et al., 2016b).

Studies involving other biological activities of products fermented with kefir have been reported in the literature. Rodrigues et al. (2016) evaluated the production of a beer using kefir as a single fermenting agent and verified the anti-inflammatory and anti-ulcerogenic activities of the product obtained. The authors investigated the polyphenol content of beers and in the tests with rats, the following parameters were determined: serum cholesterol, triacylglycerol, HDL cholesterol, as well as the enzymatic activities of alanine 
aminotransferase, aspartate aminotransferase, catalase and glutathione peroxidase. The results showed that the administration of beer in the animals markedly reduced the inflammatory and ulcerogenic processes. According to the authors, the results obtained suggest a special functionality of a beer made with kefir as a single fermenter. It is important to point out that the determinations carried out in the aforementioned study involve mechanisms directly correlated with the antioxidant compounds of the beer.

\section{Conclusion}

From the results obtained, we conclude that the independent variables agitation and incubation temperature exerted significant effects on the antioxidant properties of lentil extracts fermented by kefir grains. The fermentation time is also directly linked to the production or biotransformation of compounds with better antioxidant properties from lentils. The conditions defined as more suitable for kefir cultivation, namely: $28^{\circ} \mathrm{C}$ as incubation temperature, $75 \mathrm{rpm}$ agitation and $4 \mathrm{~h}$ of fermentation, resulted in extracts with high antioxidant activity and percentage gains of up to $270 \%$ in comparison to the non-fermented samples. Therefore, these results are promising to help in future studies related to the fermentation of lentils by kefir, as well as in research with different substrates.

\section{References}

Agil, R., Gaget, A., Gliwa, J., Avis, T. J., Willmore, W. G., \& Hosseinian, F. (2013). Lentils enhance probiotic growth in yogurt and provide added benefit of antioxidant protection. Lebensmittel-Wissenschaft + Technologie, 50(1), 45-49. http://dx.doi.org/10.1016/j.Iwt.2012.07.032

Amorim, F. G., Coitinho, L. B., Dias, A. T., Friques, A. G. F., Monteiro, B. L., Rezende, L. C. D., Pereira, T. M. C., Campagnaro, B. P., De Pauw, E., Vasquez, E. C., \& Quinton, L. (2019). Identification of new bioactive peptides from Kefir milk through proteopeptidomics: Bioprospection of antihypertensive molecules. Food Chemistry, 282, 109-119. PMid:30711094. http://dx.doi.org/10.1016/j.foodchem.2019.01.010

Bautista-Expósito, S., Peñas, E., Dueñas, M., Silván, J. M., Frias, J., \& Martínez-Villaluenga, C. (2018). Individual contributions of Savinase and Lactobacillus plantarum to lentil functionalization during alkaline pH-controlled fermentation. Food Chemistry, 257, 341-349. PMid:29622220. http://dx.doi.org/10.1016/j.foodchem.2018.03.044

Benzie, I. F. F., \& Strain, J. J. (1996). The ferric reducing ability of plasma (FRAP) as a measure of "Antioxidant Power": The FRAP assay. Analytical Biochemistry, 239(1), 70-76. PMid:8660627. http://dx.doi.org/10.1006/abio.1996.0292

Bougatef, A., Hajji, M., Balti, R., Lassoued, I., Triki-Ellouz, Y., \& Nasri, M. (2009). Antioxidant and free radical-scavenging activities of smooth hound (Mustelus mustelus) muscle protein hydrolysates obtained by gastrointestinal proteases. Food Chemistry, 114(4), 1198-1205. http://dx.doi.org/10.1016/j.foodchem.2008.10.075

Fiorda, F. A., Pereira, G. V. M., Soccol, V. T., Rakshit, S. K., \& Soccol, C. R. (2016a). Evaluation of a potentially probiotic nondairy beverage developed with honey and kefir grains: Fermentation kinetics and storage study. Food Science \& Technology International, 22(8), 732-742. PMid:27118768. http://dx.doi.org/10.1177/1082013216646491

Fiorda, F. A., Pereira, G. V. M., Soccol, V. T., Medeiros, A. P., Rakshit, S. K., \& Soccol, C. R. (2016b). Development of kefirbased probiotic beverages with DNA protection and antioxidant activities using soybean hydrolyzed extract, colostrum and honey. Food Science and Technology, 68, 690-697. http://dx.doi.org/10.1016/j.Iwt.2016.01.003

Fiorda, F. A., Pereira, G. V. M., Thomaz-Soccol, V., Rakshit, S. K., Pagnoncelli, M. G. B., Vandenberghe, L. P. S., \& Soccol, C. R. (2017). Microbiological, biochemical, and functional aspects of sugary kefir fermentation: A review. Food Microbiology, 66, 86-95. PMid:28576377. http://dx.doi.org/10.1016/j.fm.2017.04.004

Gulitz, A., Stadie, J., Wenning, M., Ehrmann, M. A., \& Vogel, R. F. (2011). The microbial diversity of water kefir. International Journal of Food Microbiology, 151(3), 284-288. PMid:22000549. http://dx.doi.org/10.1016/j.jffoodmicro.2011.09.016

Gunenc, A., Yeung, M. H., Lavergne, C., Bertinato, J., \& Hosseinian, F. (2017). Enhancements of antioxidant activity and mineral solubility of germinated wrinkled lentils during fermentation in kefir. Journal of Functional Foods, 3, 72-79. http://dx.doi.org/10.1016/j.jff.2017.02.016

Prado, M. R., Blandón, L. M., Vandenberghe, L. P. S., Rodrigues, C., Castro, G. R., Thomaz-Soccol, V., \& Soccol, C. R. (2015) Milk kefir: Composition, microbial cultures, biological activities, and related products. Frontiers in Microbiology, 6, 1177. PMid:26579086. http://dx.doi.org/10.3389/fmicb.2015.01177

Prieto, P., Pineda, M., \& Aguilar, M. (1999). Spectrophotometric quantitation of antioxidant capacity through the formation of a phosphomolybdenum complex: Specific application to the determination of vitamin E. Analytical Biochemistry, 269(2), 337-341. PMid:10222007. http://dx.doi.org/10.1006/abio.1999.4019

Reis, S. A., Conceição, L. L., Dias, M. M., Siqueira, N. P., Rosa, D. D., Oliveira, L. L., Matta, S. L. P., \& Peluzio, M. C. G. (2019). Kefir reduces the incidence of pre-neoplastic lesions in an animal model for colorectal cancer. Journal of Functional Foods, 53, 1-6. http://dx.doi.org/10.1016/j.jff.2018.11.050 
Rodrigues, K. L., Araújo, T. H., Schneedorf, J. M., Ferreira, C. S., Moraes, G. O. I., Coimbra, R. S., \& Rodrigues, M. R. (2016). A novel beer fermented by kefir enhances anti-inflammatory and anti-ulcerogenic activities found isolated in its constituents. Journal of Functional Foods, 21, 58-69. http://dx.doi.org/10.1016/j.jff.2015.11.035

Roesler, R., Catharino, R. R., Malta, L. G., Eberlin, M. N., \& Pastore, G. (2007). Antioxidant activity of Annona crassiflora: Characterization of major components by electrospray ionization mass spectrometry. Food Chemistry, 104(3), 1048-1054. http://dx.doi.org/10.1016/j.foodchem.2007.01.017

Simsek, S., El, S. N., Kancabas Kilinc, A., \& Karakaya, S. (2014). Vegetable and fermented vegetable juices containing germinated seeds and sprouts of lentil and cowpea. Food Chemistry, 156, 289-295. PMid:24629970. http://dx.doi.org/10.1016/j.foodchem.2014.01.095

Torino, M. I., Limón, R. I., Martínez-Villaluenga, C., Mäkinen, S., Pihlanto, A., Vidal-Valverde, C., \& Frias, J. (2013). Antioxidant and antihypertensive properties of liquid and solid state fermented lentils. Food Chemistry, 136(2), 1030-1037. PMid:23122159. http://dx.doi.org/10.1016/j.foodchem.2012.09.015

Tu, C., Azi, F., Huang, J., Xu, X., Xing, G., \& Dong, M. (2019). Quality and metagenomic evaluation of a novel functional beverage produced from soy whey using water kefir grains. Lebensmittel-Wissenschaft + Technologie, 113, 108258. http://dx.doi.org/10.1016/j.Iwt.2019.108258

Viana, R. O., Magalhães-Guedes, K. T., Braga Junior, R. A., Dias, D. R., \& Schwan, R. F.. . (2017). Fermentation process for production of apple-based kefir vinegar: Microbiological, chemical and sensory analysis. Brazilian Journal of Microbiology, 48(3), 592-601. PMid:28283415. http://dx.doi.org/10.1016/j.bjm.2016.11.006

Wang, N., \& Toews, R. (2011). Certain physicochemical and functional properties of fibre fractions from pulses. Food Research International, 44(8), 2515-2523. http://dx.doi.org/10.1016/j.foodres.2011.03.012

Wiriyaphan, C., Chitsomboon, B., \& Yongsawadigul, J. (2012). Antioxidant activity of protein hydrolysates derived from threadfin bream surimi byproducts. Food Chemistry, 132(1), 104-111. PMid:26434269. http://dx.doi.org/10.1016/j.foodchem.2011.10.040

Zare, F., Champagne, C. P., Simpson, B. K., Orsat, V., \& Boye, J. I. (2012). Effect of the addition of pulse ingredients to milk on acid production by probiotic and yoghurt starter cultures. Food Science and Technology, 45, 155-160. http://dx.doi.org/10.1016/j.Iwt.2011.08.012

Zhang, B., Deng, Z., Ramdath, D. D., Tang, Y., Chen, P. X., Liu, R., Liu, Q., \& Tsao, R. (2015). Phenolic profiles of 20 Canadian lentil cultivars and their contribution to antioxidant activity and inhibitory effects on a-glucosidase and pancreatic lipase. Food Chemistry, 172, 862-872. PMid:25442631. http://dx.doi.org/10.1016/j.foodchem.2014.09.144 